\title{
Processing of Non-Fermented Sour-Sweet-Slices of Cucumbers (Cucumis Sativum L)
}

\author{
Karl Kaack \\ Department of Food Science, University of Aarhus, Aarslev, Denmark
}

\begin{abstract}
This research is concentrated about the effects of prickling, blanching, storage temperature and time focusing on establishment of equilibrium, drained weight and firmness of small sour-sweet cucumber that are used on rye bread and as an ingredient to dinner foods. Drained weight of pickled cucumber increased significantly with storage time up to 114 days whereas drained weight of non-pickled cucumber decreased up to storage for 187 days. Soluble solids and acidity were significantly higher for pickled cucumber in comparison to non-pickled cucumber. Soluble solids and acidity was non-significantly different for pickled and non-pickled cucumber and brine components. Drained weight increased significantly with days of storage up to 10 min by blanching at $72{ }^{\circ} \mathrm{C}$ and $12 \mathrm{~min}$ at $85^{\circ} \mathrm{C}$. Drained weight was significantly higher by blanching at $85^{\circ} \mathrm{C}$ in comparison to blanching at $72{ }^{\circ} \mathrm{C}$. The increase in drained weight after blanching at $85^{\circ} \mathrm{C}$ was $30 \mathrm{~g}$ in comparison to $12 \mathrm{~g}$ after blanching at $72{ }^{\circ} \mathrm{C}$. Cucumber firmness increased on average $7 \mathrm{~kg}$ during blanching at $72{ }^{\circ} \mathrm{C} \mathrm{min}$, whereas the firmness decreased $27 \mathrm{~kg}$ during blanching at $85^{\circ} \mathrm{C}$. Drained weight increased significantly with storage time, while firmness decreased significantly with storage time. Storage of pickled cucumber at 12 and $20{ }^{\circ} \mathrm{C}$ did not result in significances in texture and cucumber weight. Blanching of pickled cucumber for $0,3,6$, 10 and 15 min and storage at 12 and $20^{\circ} \mathrm{C}$ showed that drained weight increased significantly with blanching time and that firmness decreased with increases in the storage temperature.
\end{abstract}

Keywords: Slicing - blanching - firmness -enzymes - browning

\section{INTRODUCTION}

This research is concentrated about the effects of prickling, blanching and storage temperature and time focusing on establishment of equilibrium, drained weight and firmness of small sour-sweet cucumber.Preserved sour sweet slices of large cucumber produced in brine with sugar, vinegar and some spices are normally used as a decoration and flavour ingredient upon several kinds of open rye bread sandwiches. They are often served with hot dishes together with different kinds of meats, eventually boiled potatoes and other vegetables or spices. The decreasing sale of this kind of cucumber could be a lack in knowledge regarding the primary cucumber properties and missing knowledge among industrial producers about how to optimize the primary processing steps regarding improvement of this delicious food. Size and regularity in form, colour, texture, sweet-sour flavour and storability are very important among the consumers and must also be one major interest for production of delicious and healthy cucumber products[1]. The major interest among horticulturists is data regarding delivering of uniform raw cucumber, storage requirements, rate of deliveries and management. Besides of these areas is knowledge about time, temperature, pasteurization, brine composition and packaging, storage conditions and storage facilities for the cucumber products to be delivered to the super markets. And therefore, it was decided to study the effects of pickling, blanching, packaging, pasteurization, and brine composition in order to optimize the quality of mall non-fermented sour-sweet pickled cucumber.

\section{MATERIALS AND METHODS}

Production of cucumbers with length 7-12 cm was washed in tap water $\left(12-13{ }^{\circ} \mathrm{C}\right)$. The cucumbers were prickled using a piece of wood with $1.4 \mathrm{~mm}$ thick nails in squares with border length $15 \mathrm{~mm}$. That tool was applied for prickling immediately before processing using size of lots with $1300 \mathrm{~g}$. Experiment one was processed using $1300 \mathrm{~g}$ non-pickled and $1300 \mathrm{~g}$ freshly pickled cucumber that was blanched at $85{ }^{\circ} \mathrm{C}$ for $6 \mathrm{~min}$ in water baths with $20 \mathrm{~L}$ water and then cooled in $20 \mathrm{~L}$ cold tap water. The jars $\left(580 \mathrm{~cm}^{3}\right)$ were packed with $315 \mathrm{~g}$ blanched cucumber and $265 \mathrm{~g}$ brine containing $37 \mathrm{w} / \mathrm{w} \%$ sugar, $2.2 \mathrm{w} / \mathrm{w} \%$ acetic acid, $2 \mathrm{~g} \mathrm{l}^{-1}$ sodium benzoate and $2 \mathrm{~g} \mathrm{l}^{-1}$ potassium sorbate. The jars with cu- 
cumber were pasteurized at $85{ }^{\circ} \mathrm{C}$ for $15 \mathrm{~min}$ in water baths and then cooled in cold tap water. The glass jars were cooled $5 \mathrm{~min}$ in water at $60{ }^{\circ} \mathrm{C}$ and in cold water at $12{ }^{\circ} \mathrm{C}$ and stored in a cooling cabinet at $12{ }^{\circ} \mathrm{C}$. Experiment two included blanching at $72{ }^{\circ} \mathrm{C}$ for $0,3,6,10$ and $15 \mathrm{~min}$ and blanching at $85^{\circ} \mathrm{C}$ for $0,3,6,9$ and 12 min and storage at $12{ }^{\circ} \mathrm{C}$.Drained weight of cucumber slices was determined after draining for $3 \mathrm{~min}$ on a standard sieve ASTM.E aperture $2.8 \mathrm{~mm}, 11 \mathrm{mesh}$ no 7, diameter $20 \mathrm{~cm}$ (Endecott's, England). The cucumbers were cut into circular pieces with thickness $6.8 \mathrm{~mm}$ using a Ditocutter (TR,Wycombe, UK). Firmness of the stored cucumbers were measured using an Instron apparatus (Instron Ltd, Food Tester model 5565, High Wycombe, U K) equipped with a Kramer-shear cell and registering the maximum force $(\mathrm{kg})$ to break $75 \mathrm{~g}$ sliced cucumber with a sample cell piston velocity $20 \mathrm{~cm} \mathrm{~min}^{-1}$.Soluble solids were determined using a refractometer (Bellingham and Stanley, RFM 800, Turnbridge,Turnbridge Wells, Kent, UK). Acidity was measured by titration with $0.1 \mathrm{~N} \mathrm{NaOH}$ (Bie and Berntsen, Rødovre, Denmark) to pH 8.1.Samples of raw, cooked and drained cucumber materials for chemical analyses were obtained by maceration of the drained slices in a minimum of double distilled water or other liquids using a Waring blender (Waring Products B012-34-BL 99, New Hartford, USA). The sensory taste panel included people age 18-28 year interested in sensory evaluation was tested for skills in the basal tastes bitterness, sourness, sweetness, saltiness and a diversity of various food odours were trained intensively in evaluation of the sensory characteristics of at least six different raw or processed fruits and at least six raw or processed vegetable foods, previously. The odour tests of cherriesin this research include from this research were carried out by twelve trained panel members in three replicates using a sensory scale with increasing points from 1 to 10 points regarding the intensity of the sensory characteristics. The aroma compounds occurring in apples with the highest content of volatiles were separated and identified using combined GC-MS. Four members of the sensory panel described on shift the odour from the GC column answering the question yes or no regarding mouldy, mutzu earthy odour. The statistical methods included one-way and multiple analysis of variance using a Statgraphic Statistical Package (Statistical Graphics, Version 4, Rockville, USA). Averages were separated using letters. Averages were separated by letters.

Table 1. Effects of prickling on drained weight, and brine compounds by blanching for 6 min at $85^{\circ} \mathrm{C}$.

\begin{tabular}{|c|c|c|c|c|c|c|c|c|c|}
\hline \multicolumn{9}{|c|}{ Cucumber } & \multicolumn{4}{c|}{ Brine } \\
\hline \multicolumn{2}{|c|}{ Drained weight, g } & \multicolumn{2}{c|}{$\begin{array}{c}\text { Soluble solids, g } \\
100 \mathrm{~g}^{-1}\end{array}$} & \multicolumn{2}{c|}{ Acidity g $100 \mathrm{~g}^{-1}$} & \multicolumn{2}{c|}{$\begin{array}{c}\text { Soluble solids, g } \\
100 \mathrm{~g}^{-1}\end{array}$} & \multicolumn{2}{c|}{ Acidity g $100 \mathrm{~g}^{-1}$} \\
\hline $\begin{array}{c}\text { prick- } \\
\text { led }\end{array}$ & $\begin{array}{c}\text { non- } \\
\text { prickled }\end{array}$ & $\begin{array}{c}\text { prick- } \\
\text { led }\end{array}$ & $\begin{array}{c}\text { non- } \\
\text { prickled }\end{array}$ & $\begin{array}{c}\text { prick- } \\
\text { led }\end{array}$ & $\begin{array}{c}\text { non- } \\
\text { prickled }\end{array}$ & $\begin{array}{c}\text { prick- } \\
\text { led }\end{array}$ & $\begin{array}{c}\text { non- } \\
\text { prickled }\end{array}$ & $\begin{array}{c}\text { prick- } \\
\text { led }\end{array}$ & $\begin{array}{c}\text { non- } \\
\text { prickled }\end{array}$ \\
\hline $289 \mathrm{a}$ & $215 \mathrm{~d}$ & $20.0 \mathrm{a}$ & $19.7 \mathrm{a}$ & $1.13 \mathrm{a}$ & $1.16 \mathrm{a}$ & $19.3 \mathrm{~b}$ & $19.8 \mathrm{~b}$ & $1.09 \mathrm{a}$ & $1.11 \mathrm{a}$ \\
\hline $299 \mathrm{~b}$ & $225 \mathrm{c}$ & $20.8 \mathrm{a}$ & $20.2 \mathrm{a}$ & $1.16 \mathrm{a}$ & $1.15 \mathrm{a}$ & $20.4 \mathrm{a}$ & $20.5 \mathrm{a}$ & $1.12 \mathrm{a}$ & $1.10 \mathrm{a}$ \\
\hline $297 \mathrm{~b}$ & $256 \mathrm{~b}$ & $19.5 \mathrm{a}$ & $20.3 \mathrm{a}$ & $1.09 \mathrm{a}$ & $1.07 \mathrm{a}$ & $19.7 \mathrm{a}$ & $19.9 \mathrm{a}$ & $1.06 \mathrm{a}$ & $1.11 \mathrm{a}$ \\
\hline $308 \mathrm{a}$ & $256 \mathrm{~b}$ & $20.9 \mathrm{a}$ & $20.2 \mathrm{a}$ & $1.15 \mathrm{a}$ & $1.14 \mathrm{a}$ & $20.6 \mathrm{a}$ & $20.3 \mathrm{a}$ & $1.11 \mathrm{a}$ & $1.10 \mathrm{a}$ \\
\hline $307 \mathrm{a}$ & $268 \mathrm{a}$ & $19.9 \mathrm{a}$ & $19.8 \mathrm{a}$ & $1.12 \mathrm{a}$ & $1.10 \mathrm{a}$ & $20.3 \mathrm{a}$ & $20.3 \mathrm{a}$ & $1.08 \mathrm{a}$ & $1.06 \mathrm{a}$ \\
\hline $300 \mathrm{a}$ & $244 \mathrm{~b}$ & $20.2 \mathrm{a}$ & $20.0 \mathrm{a}$ & $1.10 \mathrm{a}$ & $1.10 \mathrm{a}$ & $20.1 \mathrm{a}$ & $20.2 \mathrm{a}$ & $1.09 \mathrm{a}$ & $1.10 \mathrm{a}$ \\
\hline
\end{tabular}

\section{RESUlts}

Drained weight of pickled cucumber increased significantly with storage time up to 114 days increased up to storage for 187 days (Table 1). Drained weight were significantly highest for pickled cucumber and increased significantly with storage time up to 114 days whereas drained weight of non-pickled cucumber were significantly lowest for non-pickled cucumber and increased up to storage for 187 days. The contents of soluble solids and acidity were non-significantly different for pickled and non-pickled cucumbers (Table 1). Drained weight increased significantly with days of storage time and up to blanching for $10 \mathrm{~min}$ by blanching at $72{ }^{\circ} \mathrm{C}$ and to $12 \mathrm{~min}$ by blanching at $85{ }^{\circ} \mathrm{C}$ (Table 2). Drained weight was significantly higher by blanching at $85^{\circ} \mathrm{C}$ in comparison to blanching at 72 ${ }^{\circ} \mathrm{C}$. The reason for this was a higher increase in drained weight at $85^{\circ} \mathrm{C}$ that was $30 \mathrm{~g}$ in comparison to $12 \mathrm{~g}$ by blanching at $72^{\circ} \mathrm{C}$.A significantly low firmness was obtained by blanching time 0 and 3 min and a maximum occurred after storage for 176 days, and thereafter firmness decreased significantly in comparison to firmness after 176 days (Table 3). After blanching for 6 min were the firmness significantly lowest after 91 days on storage and significantly increases was found for the remaining part of the storage period. The pattern of data from blanching at $85^{\circ} \mathrm{C}$ for 0 min was almost equal to the data obtained by blanching for $0 \mathrm{~min}$ at $72^{\circ} \mathrm{C}$. However, the firmness at all storage days was significantly highest by further blanching of the cucumber at $85^{\circ} \mathrm{C}$.This pattern included a significant higher firm- 
ness after two-step blanching that is due to pectinolytic and cellulytic enzyme activities. The explanation is that the increases in firmness are related to hydrolysis of pectins and cellulose into sugar acids with a large number of free carboxylic acid groups. These carboxylic acids are recombined by divalent mineral ions such as $\mathrm{Ca}^{++}$and $\mathrm{Mg}^{++}[1,2,3$, as described previously for firming of potatoes and green beans [5, 7]. Further increases in firmness occurred by increase of the blanching temperature from 72 to $85^{\circ} \mathrm{C}$ (Table 3). The increases in firmness during blanching at $85^{\circ} \mathrm{C}$ resulted in maximum firmness $397,387,380,367$ and $361 \mathrm{~kg}$ for $0,3,6,9$ and 12 min that may be compared with 376,383 , 377,375 , and $384 \mathrm{~kg}$ found for blanching at $72^{\circ} \mathrm{C}$. On the basis of these data it was concluded that further blanching at $85^{\circ} \mathrm{C}$ resulted in further increases in firmness and the decreases occurred by blanching for 9 and $12 \mathrm{~min}$. The temperature in the middle of two cucumbers with diameter 2.0 and $2.9 \mathrm{~cm}$ reached $72{ }^{\circ} \mathrm{C}$ after 13.5 and $16.5 \mathrm{~min}$, respectively, which may be considered as sufficient blanching time at these temperatures.Data from evaluation of the effect of blanching of cucumber slices at $80{ }^{\circ} \mathrm{C}$ previously has shown that browning may be a serious problem using short blanching times and by storage of cucumber slices and whole pickled cucumber at temperatures above $5{ }^{\circ} \mathrm{C}$ [7]. An experiment with storage of pickled cucumber showed that drained weight increased significantly with storage time, while firmness decreased significantly with storage time. Storage of pickled cucumber at 12 and $20{ }^{\circ} \mathrm{C}$ did not result in significance. An experiment with blanching of pickled cucumber for $0,3,6,10$ and 15 min and storage at 12 and $20^{\circ} \mathrm{C}$ showed that drained weight increased significantly with blanching time and that firmness decreased with increases in the storage temperature (Table 4).

Table 2. Drained weight of cucumber blanched at 72 and $85^{\circ} \mathrm{C}$ for 0 to 12 min and cool storage at $12{ }^{\circ} \mathrm{C}(n=$ 20).

\begin{tabular}{|c|c|c|c|c|c|c|c|c|c|c|}
\hline Time & \multicolumn{4}{|c|}{ Blanching at $72{ }^{\circ} \mathrm{C}, \min$} & \multicolumn{5}{|c|}{ Blanching at $85{ }^{\circ} \mathrm{C}$ min } \\
\hline Days & 0 & 3 & 6 & 9 & 12 & 0 & 3 & 6 & 9 & 12 \\
\hline 91 & $294 \mathrm{~d}$ & $302 \mathrm{c}$ & $308 \mathrm{~b}$ & $311 \mathrm{a}$ & $310 \mathrm{a}$ & $284 \mathrm{e}$ & $302 \mathrm{~d}$ & $306 \mathrm{c}$ & $313 \mathrm{~b}$ & $319 \mathrm{a}$ \\
\hline 176 & $306 \mathrm{~b}$ & $305 \mathrm{~b}$ & $309 \mathrm{~b}$ & $314 \mathrm{a}$ & $315 \mathrm{a}$ & $292 \mathrm{e}$ & $306 \mathrm{~d}$ & $312 \mathrm{c}$ & $317 \mathrm{~b}$ & $321 \mathrm{a}$ \\
\hline 272 & $307 \mathrm{a}$ & $310 \mathrm{a}$ & $316 \mathrm{a}$ & $316 \mathrm{a}$ & $314 \mathrm{a}$ & $293 \mathrm{~d}$ & $311 \mathrm{c}$ & $316 \mathrm{~b}$ & $320 \mathrm{a}$ & $322 \mathrm{a}$ \\
\hline 327 & $301 \mathrm{c}$ & $310 \mathrm{a}$ & $314 \mathrm{a}$ & $315 \mathrm{a}$ & $314 \mathrm{a}$ & $294 \mathrm{~d}$ & $309 \mathrm{c}$ & $314 \mathrm{~b}$ & $316 \mathrm{~b}$ & $320 \mathrm{a}$ \\
\hline Average & $302 \mathrm{c}$ & $307 \mathrm{~b}$ & $312 \mathrm{a}$ & $314 \mathrm{a}$ & $313 \mathrm{a}$ & $291 \mathrm{e}$ & $307 \mathrm{~d}$ & $312 \mathrm{c}$ & $317 \mathrm{~b}$ & $321 \mathrm{a}$ \\
\hline
\end{tabular}

Table 3. Firmness of sour-sweet cucumber blanched at 72 and $85{ }^{\circ} \mathrm{C}$ for 0 to $12 \min (n=20)$.

\begin{tabular}{|c|c|c|c|c|c|c|c|c|c|c|}
\hline Days & \multicolumn{4}{|c|}{ Blanching at $72{ }^{\circ} \mathrm{C}, \min$} & \multicolumn{5}{c|}{ Blanching at $85{ }^{\circ} \mathrm{C}$ min } \\
\hline & 0 & 3 & 6 & 10 & 12 & 0 & 3 & 6 & 9 & 12 \\
\hline 91 & $362 \mathrm{c}$ & $374 \mathrm{~b}$ & $367 \mathrm{~b}$ & $371 \mathrm{~b}$ & $365 \mathrm{c}$ & $389 \mathrm{~b}$ & $377 \mathrm{c}$ & $366 \mathrm{c}$ & $356 \mathrm{c}$ & $350 \mathrm{c}$ \\
\hline 176 & $376 \mathrm{a}$ & $383 \mathrm{a}$ & $375 \mathrm{a}$ & $375 \mathrm{a}$ & $370 \mathrm{~b}$ & $397 \mathrm{a}$ & $385 \mathrm{a}$ & $377 \mathrm{a}$ & $363 \mathrm{~b}$ & $357 \mathrm{~b}$ \\
\hline 272 & $369 \mathrm{~b}$ & $369 \mathrm{c}$ & $376 \mathrm{a}$ & $371 \mathrm{~b}$ & $384 \mathrm{a}$ & $385 \mathrm{c}$ & $381 \mathrm{~b}$ & $380 \mathrm{a}$ & $367 \mathrm{a}$ & $356 \mathrm{~b}$ \\
\hline 327 & $363 \mathrm{c}$ & $369 \mathrm{c}$ & $377 \mathrm{a}$ & $371 \mathrm{~b}$ & $381 \mathrm{a}$ & $382 \mathrm{c}$ & $387 \mathrm{a}$ & $374 \mathrm{~b}$ & $356 \mathrm{c}$ & $361 \mathrm{a}$ \\
\hline
\end{tabular}

Table 4. January. Sensory properties after storage for 7 months.

\begin{tabular}{|c|c|c|c|c|}
\hline Blanching at $80^{\circ} \mathrm{C}$, min & 0 & 3 & 6 & 9 \\
\hline Browning, row no (1 to 5) & $3.3 \mathrm{a}$ & $2.5 \mathrm{~b}$ & $2.5 \mathrm{c}$ & $1.8 \mathrm{~d}$ \\
\hline Firmness, row no (1 to 10$)$ & $7.1 \mathrm{a}$ & $7.0 \mathrm{a}$ & $5.6 \mathrm{~b}$ & $5.6 b$ \\
\hline Pasteurization at $75^{\circ} \mathrm{C}$, min & 15 & 30 & 45 & 60 \\
\hline Browning, point (1 to 5) & $2.5 \mathrm{a}$ & $2.5 \mathrm{a}$ & $2.6 \mathrm{a}$ & $2.4 \mathrm{~b}$ \\
\hline Firmness, row no (1 to10) & $6.6 \mathrm{~b}$ & $7.7 \mathrm{a}$ & $7.4 \mathrm{a}$ & $6.3 b$ \\
\hline Storage temperature, ${ }^{\circ} \mathrm{C}$ & 5 & 10 & 15 & 20 \\
\hline Browning after 7 months (1 to 5) & $1.0 \mathrm{a}$ & $2.0 \mathrm{~b}$ & $3.0 \mathrm{c}$ & $4.0 \mathrm{~d}$ \\
\hline Firmness after 7 months ( 1 to10) & $8.4 \mathrm{a}$ & $7.6 \mathrm{a}$ & $6.0 \mathrm{~b}$ & $5.8 \mathrm{~b}$ \\
\hline Ascorbic acid, mg $1.2 \mathrm{~kg}^{-1}$ & 0 & 83 & 166 & 333 \\
\hline Browning (1 to 5) & $1.5 \mathrm{~d}$ & $2.5 \mathrm{c}$ & $3.0 \mathrm{~b}$ & $3.8 \mathrm{a}$ \\
\hline Firmness, point & $6.3 a$ & $5.9 \mathrm{~b}$ & $5.4 \mathrm{c}$ & $5.1 \mathrm{~d}$ \\
\hline
\end{tabular}

\section{DisCUSSION}

According to table 1 resulted prickling in a considerable and significantly increase in drained weight that in comparison with non-pickled cucumber may cause a more delicious texture and flavour [5]. The data from determination of soluble solids and acetic acid showed that an almost complete equilibrium was obtained for soluble solids an acetic acid in pickled and non-pickled cucumber, whereas the 
drained weight of pickled cucumber were significantly higher if the cucumber are pickled in comparison to non-pickled cucumber (Table 1).Drained weight increased significantly with treatment time at both blanching temperatures and the data shows that a higher blanching temperature result in a higher drained weight (Table 2).Equilibration between whole cucumbers and the brine was found to be consistent with a controlled first-order rate process for attainment of equilibrium for sugar and malic acid from the cucumbers to the brine and by $\mathrm{NaCl}$ and acetic acid [6].The rates of equilibrium were much higher for peeled cucumbers in comparison to the equilibration rate for non-peeled fruits and they increased by raising temperatures for sugar, malic acid and $\mathrm{NaCl}$ [6]. Attainment of equilibrium for solutes was linearly related to time. Significantly differences changes was obtained during blanching for 10 and 15 minutes at the temperature $72{ }^{\circ} \mathrm{C}$, while equality by blanching at $85^{\circ} \mathrm{C}$ was obtained after the longest treatment time $12 \mathrm{~min}$. The change in firmness by blanching at $85^{\circ} \mathrm{C}$ decreases on average with blanching time (Table 3), which is quite clear regarding the averages. Based on these data it was concluded that firmness decreased significantly with blanching time. Another conclusion may be that there is a significant difference regarding blanching at the two temperatures because of the changes in firmness that may be considered as very satisfying to use $72{ }^{\circ} \mathrm{C}$ because a lower blanching temperature may result in lower decreases in dry matter that may be considered as very valuable and reduce the cost by processing. According to the data presented above increases the firmness very little by blanching at $72{ }^{\circ} \mathrm{C}$ with firmness $\mathrm{f}=370+0.3 \mathrm{~kg}$ and using higher temperatures resulted in less firm cucumber with $\mathrm{f}=390-2.88 \mathrm{~min}$.

Table 5. Drained weight and firmness at $72{ }^{\circ} \mathrm{C}$ and $85^{\circ} \mathrm{C}$.

\begin{tabular}{|c|c|c|c|c|c|}
\hline & \multicolumn{2}{|c|}{ Drained weight, $\mathrm{g}$} & \multicolumn{3}{c|}{ Firmness, $\mathrm{kg}$} \\
\hline Min & $72{ }^{\circ} \mathrm{C}$ & $85{ }^{\circ} \mathrm{C}$ & Min & $72{ }^{\circ} \mathrm{C}$ & $85^{\circ} \mathrm{C}$ \\
\hline 0 & 0 & 291 & 0 & 368 & 388 \\
\hline 3 & 307 & 307 & 3 & 374 & 377 \\
\hline 6 & 312 & 312 & 6 & 374 & 374 \\
\hline 10 & 314 & 317 & 10 & 371 & 356 \\
\hline 15 & 313 & 321 & 15 & 375 & 361 \\
\hline
\end{tabular}

Cucumbers contain pectin esterase that may de-methylate pectins in the cell walls and cause serious softening of the cucumber tissue during storage if they not are blanched sufficiently [2]. In some cases must softening be avoided or require use of calcium chloride that are connecting the pectin molecules together and make the cucumber products qualified because of a properly tissue strength [8]. An example could be blanching of cucumber with a low content of calcium that may need extra heating in order to inactivate pectinesterase and decrease the content of glycosides that are present in cucumber [9].Precondition conditioning of cucumber tissues by pre-blanching may result in improvement of cucumber firmness and retention of a white appearance of cucumber tissues if they are processed within one hour or within 24-28 hours after pre-condition[10].Firmness decreased by blanching from $16.5 \mathrm{~N}$ to $7.0 \mathrm{~N}$ for 12 hours using pectinesterase and glucosidase [11]. During storage increased firmness losses with increasing temperature and $\mathrm{pH}$ and firmness decreased with increasing content of salt due to interaction between temperature and $\mathrm{pH}$ [12]. Blanchingmay result in improvement of cucumber firmness and improve the white appearance of cucumber [10]. Improvement of firmness may be attributed to formation of calcium pectate that improves the middle lamella cell wall rigidity [8]. Carbohydrates, water soluble pectins, and sodium hexametaphosphate-soluble pectin were significantly correlated with shear press and sensory firmness. Cucumber tissues may be cured using knowledge about rates of cucumber tissue including the effects of $\mathrm{pH}$, calcium, and temperature $[8,9]$. Softening of cucumber tissue may occur because of a low content of calcium and may be reduced using calcium because demethylation of fresh $\mathrm{Ca}$-pectates that improves cell wall rigidity and improved resistances against polygalacturonase [13]. The relation between polygalacturonase was hyperbolic and that means that $\log 10$ versus time is a straight line [14]. A low content of Calcium may result in a lower firmness. Pectic substances of fresh cucumber tissue are from $35-50 \%$ deesterefied and the free acid groups may react with minerals such as calcium $\mathrm{Ca}++$ and $\mathrm{Mg}++$ and that result in strong connections between various pectin molecules that increase the number of bindings between various pectins in cucumber. A low content of calcium may result in low firmness [11]. Both calcium and $\mathrm{NaCl}$ prevented both enzymatic [14] and non-enzymatic softening of cucumber [8].Polyphenol oxidase (Tyrosinase) catalyses hydroxylation of monophenols and promote oxidation of the O-diphenoles to O-quinones that may cause severe browning of cucumber tissue [15].Enzymatic browning of fruits and vegetables is therefore mostly related to oxidation of endogenous phenolic compounds that ulti- 
mately leads to the formation of dark brown polymers of a quinoidal nature. That situation requires blanching of cucumbers in order to avoid a serious loss in consumer qualities. Peroxidase constitutes a group of enzymes (glycoproteins) whose main function is oxidation of different substrates at the expense of $\mathrm{H}_{2} \mathrm{O}_{2}$ [2]. These enzymes are also involved in lignification, hormone metabolism, and response to stress in plant tissues. It is also necessary to inactivate the thermo-stable peroxidase because this enzyme may cause adverse flavour and colour in short time after processing. A test for presence or absence of peroxidase is necessary in order to avoid severe development of various aroma compounds in processed fruits and vegetables [12]. Ascorbic acid induced browning of (+)-catechin in a model wine system has been studied. A significant increase in absorbance at $440 \mathrm{~nm}$ was observed over 14 days when ascorbic acid was incubated at $45^{\circ} \mathrm{C}$ with (+)-catechin in a model wine base. The onset of browning was delayed for about 2 days, although the length of the lag period was dependent on the amount of molecular oxygen in the headspace of the reaction system. The lag period was not observed when a pre-oxidized solution of ascorbic acid was used, suggesting that a product of ascorbic acid oxidation is responsible for the onset of browning [13].Ascorbic acid was a very efficient antioxidant against formation of hexanal, $(E)$-2-penenal, $(E)$-2-hexenal, $(E)$-2-heptenal, and $(E)$-2octenal when slurries of fermented cucumber tissue were exposed to oxygen and most of these oxidative was efficiently prevented at $1755 \mathrm{ppm}$ [14].Non-chemical browning of cucumber includes interactions of amino acids and sugars at various levels of $\mathrm{pH}$ that could affect the colour of cucumber by non-enzymatic browning through several kinetic reactions that would reduce the contents of amino acids and sugars $[11,20]$. Model experiments showed that the level of 5-hydroxymethylfurfural (5$\mathrm{hmf}$ ) at $\mathrm{pH} 3.5$ from fructose was 31.2 times faster than glucose, whereas sucrose was 18.5 times faster than glucose [21]. The contents of citric acid, calcium, magnesium, potassium, and the amino acids alanine, aspartic acid, and $\gamma$-aminobutyric acid could accelerate formation of 5hydroxylfumerate.Model systems were employed to determine the relative reactivity of sucrose, glucose, and fructose in the formation of 5-hydroxymethylfurfural (5-hmp) at $\mathrm{pH} 3.5$. Fructose was the major reactant for formation of 5-HMF because this carbohydrate was 31.2 times faster than glucose, while sucrose was faster than glucose in the rate of 5-HMF formation when averaged over three different sugar-catalyst systems[22]. Accelerating effects of citric acid, minerals (calcium, magnesium, and potassium), and amino acids (alanine, aspartic acid, and $\gamma$-aminobutyric acid) in the formation of 5-HMF from sugars were evaluated. With fructose as the substrate was 5-HMF produced 5 times faster by presence of citric acid and minerals than in the presence of $\mathrm{HCl}$. Varying catalytic effects were noted with the three amino acids. Formation of 5-HMF formation from glucose and sucrose was enhanced by presence of the amino acids, whereas virtually no enhancement occurred when fructose was the substrate [23].Large whole cucumbers (size no. 4) were fermented and held in solutions containing low $\mathrm{NaCl}$ with and without $\mathrm{CaCl}_{2}$, at $24^{\circ} \mathrm{C}$ for one and four 4 months. Firmness of pericarp tissues (centre) of pickles exposed to $\mathrm{CaCl}_{2}$, was much greater than of pickles not exposed to $\mathrm{CaCl}_{2}$, after 1 and 4 months in storage. Locular tissue of pickles not exposed to $\mathrm{CaCl}_{2}$, softened dramatically between 1 and 4 months in storage and after 4 months were the centres of cucumber extremely soft. In contrast, centre of pickles exposed to $\mathrm{CaCl}_{2}$, were firm and intact after 1 and 4 months. Addition of $\mathrm{CaCl}_{2}$, to fermentation and storage brines appears to provide a simple method for pickle improvement. Pasteurization of pickle products for $15 \mathrm{~min}$ until $73{ }^{\circ} \mathrm{C}$ in the jar centre was adequate to avoid spoiling [24] and pasteurizing for $25 \mathrm{~min}$ at $82{ }^{\circ} \mathrm{C}$ was enough time to reduce the level of microorganism and peroxidase to an acceptable level [25], whereas pasteurizing of pickled cucumber at $75,80,85$ and $90{ }^{\circ} \mathrm{C}$ for $22.0,19.5,14.5$ and $4 \mathrm{~min}$, indicated that an residual activity of polygalacturonase could be expected in the pasteurized pickle products $[26,27]$.

Pasteurization of cucumber at internal product temperature $71-76^{\circ} \mathrm{C}$ followed by prompt cooling may be considered as efficient to avoid spoilage and result in a high quality of pickled cucumber [28]. Optimum degree of esterification in order to obtain an optimum firmness was between 10 and 12 newton[29].Firmness of cucumber pasteurized at $74{ }^{\circ} \mathrm{C}$ was spoiled after 120,30 and 30 min using water, acetic acid and lactic acid in the brine at $74{ }^{\circ} \mathrm{C}$, respectively [30]. Acetic acid caused the least loss in firmness, followed by lactic, citric, malic and oxalic acids [30] and peroxidase activity in cucumber prickles decreased significantly during the first four days in cucumber without and with $\mathrm{CaCl}_{2}$, while peroxidase in the brine increased during the first week and decreased during the second week, respectively. Firmness decreased with increased by rising temperature and $\mathrm{pH}$, whereas firmness increased with increases in salt and the interaction between temperature and $\mathrm{pH}$ [31]. The damage on texture may be severe $20^{\circ} \mathrm{C}$ and especially by higher temperature. 


\section{REFERENCES}

[1] Cook, J.A., Pflug, I.J., Ries, S.K., Effect of cucumber holding time and temperature on the quality of Pasteurized fresh whole pickles. Food Technol. 11, 216-218. (1956).

[2] Bea,T.A., Etchells, J.L., Jones, I.D., Softening of commercial cucumber salt-stock in relation to polygalacturonase activity. Food Technol.4, 157-163. (1950).

[3] Bell, B.A., Etchells, J.L., Jones, I.D., Pectinesterase in the cucumber. Arch. Biochem.31,431442. (1951).

[4] Bell, T., Etchelles J.L., Influence of salt $(\mathrm{NaCl})$ on pectinolytic softening of cucumbers. J. Food Sci.26, 84-90. (1961).

[5] Rodrigo, M., Alvarruiz, A., The Influence of fermentation and pasteurization on the texture of cucumber pickles. J. Food Eng.7, 113-125. (1988).

[6] Potts, E.A., Fleming, H.P., McFeeters, R.F., Guinnup, D.G., Equilibration of solutes in nonfermenting, brined pickling cucumbers. J. Food Sci. 51, 434-439. (1986).

[7] Kaack K., Blanching of green bean (Phaseolus vulgarisL). Plant Foods for Human Nutriion 46, 353-360. (1994).

[8] Buescher, R.W., Hudson, J.M., Bound cations in cucumber pickle mesocarp tissue as affected by brining and $\mathrm{CaCl}_{2} \mathrm{~J}$. Food Sci.51, 135-137. (1986).

[9] Maruvada, R., McFeeters, R.F., Evaluation of enzymatic and non-enzymatic softening in low salt cucumber fermentations. Int. J. Food Sci. Technol. 44, 1108-1117. (2009).

[10] Cho., M.J., Buescher, R.W., Potential role of native pickling cucumber polygalacturonase in softening of fresh-pack pickles. J. Food Sci. 77, C443-C447. (2012).

[11] Ajandouz, E.H., Puigserver A., Non-enzymatic browning reaction of essential amino acids. Effect of $\mathrm{pH}$ on caramelization and Maillard reaction kinetics. J. Agric. Food Chem.47, 17861793.(1999).

[12] Burnette, E.F.S., Peroxidase and its relationship to food flavor and quality. Food Technol. 42, 16. (2006).

[13] Bradshaw, M.P., Prenzer, P.D., Scollary, G.R., Ascorbic acid-induced browning of (+)-catechin in a model wine system.J. Agric. Food Chem.49, 934-939. (2001).

[14] Zhou, R., McFeeters F., Fleming, H.P., Development of oxidized odour and volatile aldehydes in fermented cucumber tissue exposed to oxygen. J. Agric. Food Chem. 48, 193-197.(2000).

[15] Bell, L.L., T.A., Jones J.L, Singleton, J.A and Smart, W.G., Inhibition of pectinolytic and cellulolytic enzymes in cucumber fermentations by Sericea. J Food Sci.301 233-239.(1965).

[16] Bell, T.A., Turneu, L.J., Etchells, J.L., Influence of different organic acids on the firmness of fresh-pack pickles. J. Food Sci. 37, 446-449. (1972).

[17] Berdoll, M.S., Holmes, E.,The heating of sucrose solutions. I. The relationship of 5hydroxymethyl-furfural to color formation J Food Sci 16, 50-56. (1951).

[18] Buescher,R.W., Hudson, J.M., Adams, J.R.,Inhibition of polygalacturonase softening of cucumber pickles by calcium chloride. J. Food Sci.44, 1786-1787.(1979).

[19] Buescher R.W., McGuire., C., Peroxidase activities in cucumber pickle products.J. Food Sci.51, 1079-1080. (1986).

[20] Buescher, R.W., McGuire., C.E., Skulman, B.,Catalase, lipoxygenase and peroxidase activities in cucumber pickles as affected by fermentation, processing and calcium chloride. J. Food Sci.52, 228-229. (1987).

[21] Buescher, R., Cho, M.J., Hamilton, C., Heat conditioning of cucumbers improves retention o sliced refrigerated pickle texture and appearance. J. Food Biochem.371, 564-570.(2013).

[22] McFeeters, R.F., Fleming, H.P., Inhibition of cucumber tissue softening in acid brines by multivalent cations. Inadequacy of pectin "EGG" model to explain textural effects. J. Food Sci.37, 1053-1059. (1988).

[23] Eichner, R.K., Karel, M., Influence of water content and water activity on the sugar-amino browning reaction in model systems under various conditions J. Agric. Food Chem.20, 218-222.

[24] Etchelles, J.L., Jones, I.D., Grepin, H., Procedure for pasteurization of pickle products. Glass Packer 98, 28-35. (1944). 
[25] GandIäa-Herrero, F., Jemenez, Z, Cabanes, J., Garciâa-Carmona,F., Escribano,J., Tyrosinase inhibitory activity of cucumber compoundsenzymes responsible for browning in cucumber. $\mathbf{J}$ Agric. Food Chem.51, 7764-7769. (2003).

[26] Hudson, J.M., Buescher, R.W., Prevention of soft center development in large whole cucumber pickles by calcium. J Food Sci.45, 1450-1451. (1980).

[27] Hudson, J,M., Buescher, R.W., Pectic substances and firmness of pickles as influenced by $\mathrm{CaCl}$, $\mathrm{NaCl}$ and storage. J. Food Biochem. 9, 211-229.(1985).

[28] Hudson, J.M., Buescher, R.W., Relationship between degree of pectin methylation and firmness of cucumber pickles. J. Food Sci.51, 138-140.(1986).

[29] Lee, H.S., Nagy., S., Relative reactivity of sugars in the formation of 5-hydroxy-methylfurfural in sugar catalyst model systems. J. Food Process Preserv.14, 171-178. (1990).

[30] Buescher, R., McFeefeters, R., F., Evaluation of enzymatic and non-enzymatic softening in low salt cucumber fermentations. Int. J. Food Sci. Technol.44, 1108-1117. (2009).

[31] McFeefeters, R.F.M., Armstrong,S.A.,Measurement of pectin methylation in plant cellwalls. Anal. Biochem. 139., 212-217. (1984).

[32] McFeeters, R.F., Fleming, H.P., Thompson, R.L., Pectinesterase activity, pectin methylation and texture changes during storage of blanched cucumber slices. J. Food Sci.50, 201-205. (1985).

[33] McFeeters, R.F., Balbuena, M. B., Fleming, H.P., Softening rates of fermented cucumber tissue. Effects of $\mathrm{pH}$, calcium, and temperature. J Food Sci 60, 786-788. (1995).

[34] Monroe, R.J., Etchells, J.L., Pacilio, J.C., Borg, A.F., Wallace, D.H., Roders, M.P., Turney, L.J., Schoene, E.S., Influence of various acidities and pasteurizing temperatures on the keeping quality of fresh-pack dill pickles. Food Technol. 23, 71-77. (1969).

[35] Thompson, R.L., Fleming, H.P., Monroe, R.J. Effects of storage conditions on firmness of brined cucumbers. J. Food Sci. 44 , 843-846. (1979). 